\title{
Uma reescritura nada sagrada: a teologia às avessas de José Saramago em Caim
}

\author{
Orientadora: Maria Clara Lucchetti Bingemer \\ Mestrando: Marcio Cappelli Alo Lopes \\ Área de Concentração: Teologia Sistemático-Pastoral \\ Linha de Pesquisa: Religião e Modernidade
}

O presente trabalho busca compreender como a crítica saramaguiana contida em Caim pode contribuir para a derrubada de imagens inautênticas de Deus. Para tal intento foi necessário seguir alguns passos sendo o primeiro percorrer o caminho de uma proposta de aproximação entre teologia e literatura. No entanto, como a literatura do autor escolhido está marcada por seu ateísmo também se impôs a tarefa de compreender como a teologia pode acolher as críticas ateístas. Já num segundo passo, à luz de um breve perfil biográfico, literário e do pensamento religioso do escritor português percebeu-se que em diversas de suas tramas opera uma reescritura lançando mão da intertextualidade, sobretudo com a Bíblia carnavalizando-a. A partir disso, concluiu-se que uma espécie paixão por questões religiosas habita inúmeros textos do escritor. Todavia, nesses textos Saramago (des)constrói compreensões acerca de representações de Deus que foram forjadas dentro do cristianismo e que ainda estão em vigor em diversos de seus ramos. Ou seja, faz sua a-telogia, ou que se pode chamar de teologia às avessas. Por fim, como último passo afunilou-se a discussão em torno do romance Caim. Nele, ao recontar diversos episódios bíblicos, o lusófono continua seu projeto de uma reescritura nada sagrada e seu labor a-teológico. Pinta através de sua pena um Deus egocêntrico, arbitrário e indiferente ao sofrimento humano. Deus esse que alguns teólogos tem tentado matar. Em suma, a crítica presente em Caim num diálogo com a teologia contribui para demolir imagens inautênticas de Deus.

Palavras-chave: José Saramago; teologia; literatura; ateísmo. 